\title{
小腸穿孔をきたしたCrohn 病の 1 手術例
}

\author{
川崎医科大学救急医学 \\ 体科良荻野 隆光 藤井 千穂
}

\begin{abstract}
42歳の男性が，突然激しい腹痛が出現したため当科へ搬入された。な招患者は約11年前から Crohn 病のため, サラゾスルファピリジン，プレドニゾロン，カナマイシンを内服していた．また 6 年前か ら小腸造影で小腸の狭窄とその口側の拡張を指摘されていた。来院時, 腹部は平坦で硬く, 白血球は $9,000 / \mathrm{mm}^{3}$, 腹部単純 $\mathrm{X}$ 線撮影で明らかな free air を認めたため, 緊急手術を施行した。小腸の抎張 部の腸間膜付着反対側に直径約 $1 \mathrm{~mm}$ の穿孔を認めた。 小腸を $80 \mathrm{~cm}$ 切除し端々吻合を行った。切除標 本では狭窄と縦走潰瘍が認められ，組織所見では肉芽腫を伴った炎症細胞浸潤の所見であった。術後 経過は良好で, 第62病日退院した. Crohn 病の長期治療中には, 穿孔の危険性も考虑すべきであるこ とを示した症例である。
\end{abstract}

Key words: free perforation of regional enteritis, Crohn's disease

Crohn 病に批合併症としては狭窄, 出血, 瘦孔 形成などがあるが，腹腔内遊離穿孔をきたすことは立 れである，今回われわれは小腸穿孔をきたしたCrohn 病の 1 例を経験したので報告する.

\section{症例}

症例：42歳, 男性

主訴：腹痛

家族歴：特記事項なし。
既往歴：16歳急性虫垂炎にて手術，26歳痔核にて手 術

現病歴：1980年に当院内科で Crohn 病を指摘され, サラゾスルファピリジン $2 \mathrm{~g}$ 内服を開始した. 1988年 7 月からプレドニゾロン $5 \mathrm{mg}$ 内服を，1989年 7 月から elemental diet 療法を追加されていた。 また1985年お よび1988年の小腸造影で, 小腸の狭窄とその口側の拡 張が認められていた（Fig. 1)。このため, 小腸内の細

Fig. 1 Small intestine series on 1985 (left) and 1988 (right) show narrowing and dilating of ileum (black arrow).
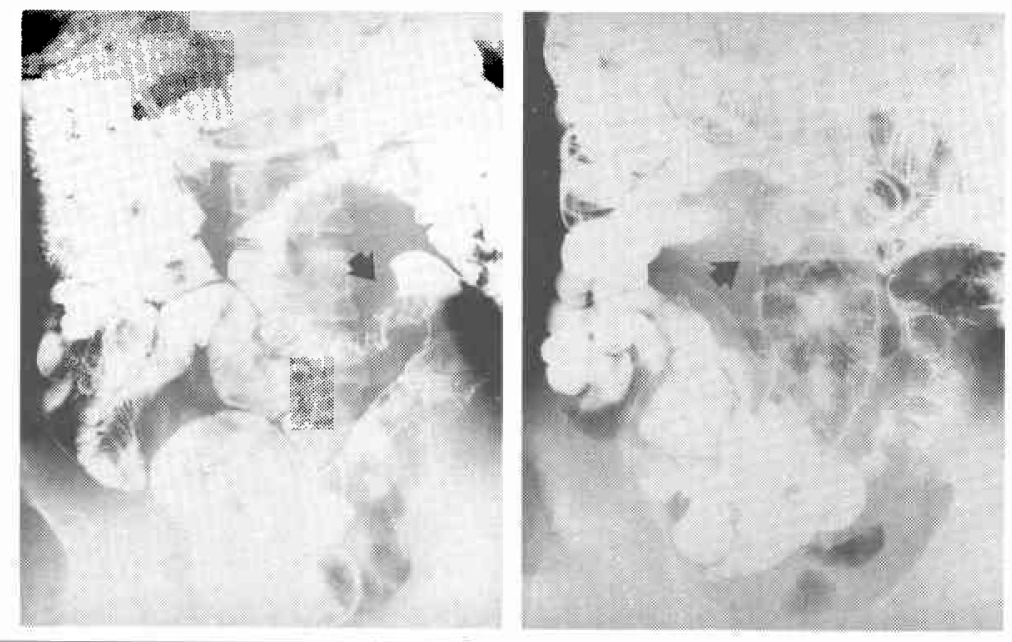

$<1991$ 年11月 20 日受理 $>$ 別刷請求先：仁科 雅良

T701-01 倉敷市松島 577 川崎医科大学救急医学 
Table 1 Laboratory data on admission

\begin{tabular}{|c|c|c|c|}
\hline WBC & $9,000 / \mathrm{mm}^{3}$ & $\mathrm{Na}$ & $143 \mathrm{mEq} / 1$ \\
\hline $\mathrm{RBC}$ & $545 \times 10^{4} / \mathrm{mm}^{3}$ & $\mathrm{~K}$ & $3.6 \mathrm{mEq} / \mathrm{l}$ \\
\hline \multirow[t]{2}{*}{$\mathrm{Ht}$} & $49.1 \%$ & SP & $6.6 \mathrm{~g} / \mathrm{dl}$ \\
\hline & & BS & $127 \mathrm{mg} / \mathrm{dl}$ \\
\hline \multirow{2}{*}{\multicolumn{2}{|c|}{$\begin{array}{r}\text { Arterial blood gas analysis } \\
\text { (room air) }\end{array}$}} & Bil & $0.7 \mathrm{mg} / \mathrm{dl}$ \\
\hline & & GPT & $12 \mathrm{IU} / \mathrm{l}$ \\
\hline $\mathrm{pH}$ & 7.389 & Amy & $339 \mathrm{IU} / 1$ \\
\hline $\mathrm{PO}_{2}$ & $94 \mathrm{mmHg}$ & & \\
\hline $\mathrm{PcO}_{2}$ & $39.0 \mathrm{mmHg}$ & & \\
\hline $\mathrm{BE}$ & $-0.4 \mathrm{mEq} / 1$ & & \\
\hline
\end{tabular}

Fig. 2 Plain abdominal X-ray film on admission shows free air under right diaphragm (left decbitus view).

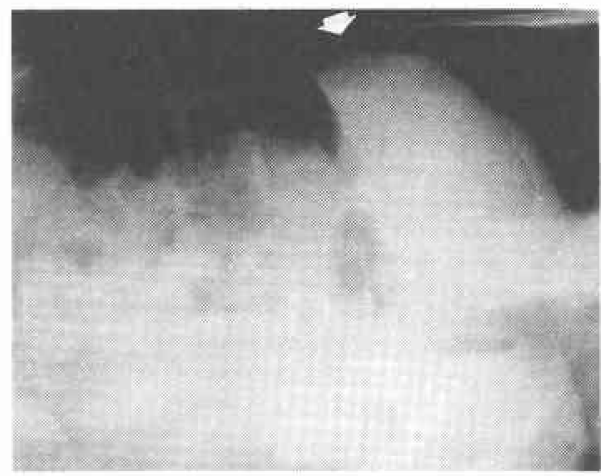

菌増殖に対して，1990年 9 月からカナマイシンを $1 \mathrm{~g}$ 内服していた。

1991年 2 月 13 日午前 2 時頃，突然激しい腹痛が出現 したため, 午前 3 時50分救急車にて当科入搬入された。 来院時現症：血王 $100 / 60 \mathrm{mmHg}$, 脈拍 $80 /$ 分, 呼吸数 $28 /$ 分, 体温 $36.7^{\circ} \mathrm{C}$. 眼䀫および眼球結膜に筫血や黄㾝 はなく，心音扣よび呼吸音にも異常を認めなかった。 腹部は平坦で硬く, 腹部全体に著明な王痛・反跳痛・ 筋性防御がみられ，腸音は消失していた，肛門指診で， ダグラス窩に圧痛を認めた。

検查所見：来院時の血液検查所見を Table 1 に示 す。白血球は $9,000 / \mathrm{mm}^{3}$ と軽度の上昇であった，腹部 単純 X 線撮影で明らかな free air を認めた（Fig. 2). 以上の所見から，消化管穿孔による汎発性腹膜炎と診 断し，緊急開腹術を施行した。

手術所見：腹腔内には多量の污濁した腹水が貯留し て㧍り，膿苔がいたるところに付着していた。 Treiz 靸 帯から $320 \mathrm{~cm}$ の回腸に狭窄があり，その口側は $50 \mathrm{~cm}$ にわたって著明に拡張していた。この拡張部の腸間膜
Fig. 3 On Operative finding, the perforation occured antimesenteric side.

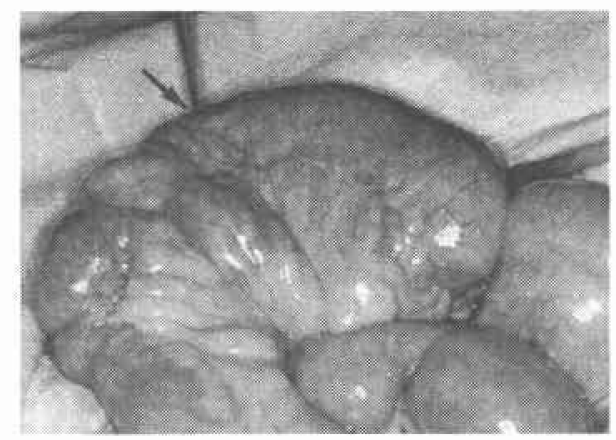

Fig. 4 Resected specimen of the ileum demonstrating stenosis and longitudinal ulcer of antimesenteric border.

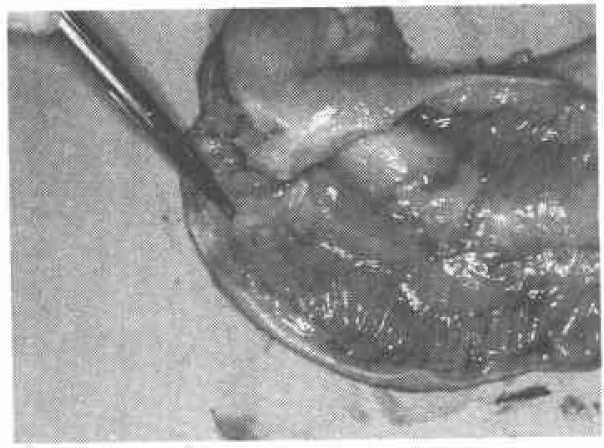

Fig. 5 Histology of the resected ileum. There is inflammatory cell infiltration with granuloma formation in every layer.

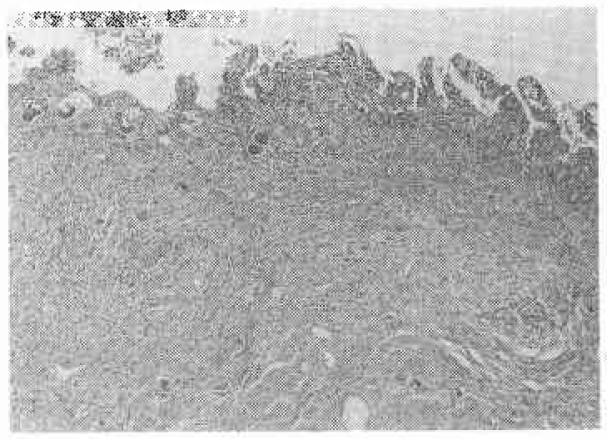

付着反対側に直径約 $1 \mathrm{~mm}$ の穿孔を認めた(Fig. 3).こ の近傍はCrohn 病に特有の腸間膜付着部の硬化を認 めたので，狭窄部を含めて小腸を $80 \mathrm{~cm}$ 切除し端々吻 合を行った。さらに離れた部分の小腸にもCrohn 病所 見が見られたが,切除の適応はないと判断し温存した。 
Table 2 Cases of free perforation of small intestine due to Crohn's disease in Japan

\begin{tabular}{|c|c|c|c|c|c|c|c|c|c|c|c|}
\hline & $\mathrm{Au}$ & ther & Age & Sex & $\begin{array}{l}\text { Dur } \\
\text { sym }\end{array}$ & $\begin{array}{l}\text { ration of } \\
\text { nptoms }\end{array}$ & $\begin{array}{l}\text { Site of } \\
\text { perforation }\end{array}$ & $\begin{array}{l}\text { Number of } \\
\text { perforation }\end{array}$ & $\begin{array}{l}\text { Steroid } \\
\text { therapy }\end{array}$ & Stenosis & Result \\
\hline 1 & 1965 & Yamase & 24 & $M$ & 1 & month & A & 1 & + & - & $S$ \\
\hline 2 & 1976 & Sekoguti & 57 & $M$ & 3 & years & $?$ & 2 & - & + & $S$ \\
\hline 3 & 1981 & Morise & 36 & $F$ & 4 & months & $M$ & 1 & - & - & $\mathrm{S}$ \\
\hline 4 & 1982 & Ohsaki & 34 & $M$ & 1 & year & $M$ & 3 & + & - & D \\
\hline 5 & 1982 & Watanabe & 20 & $M$ & 5 & hours & $M$ & 1 & - & - & $\mathrm{S}$ \\
\hline 6 & 1983 & Tamura & 29 & $M$ & 1 & day & $M$ & 1 & - & - & $\mathrm{S}$ \\
\hline 7 & 1983 & Uchida & 92 & $F$ & 1 & day & $M$ & 2 & - & + & $D$ \\
\hline 8 & 1983 & Katsumata & 23 & $M$ & 7 & months & A & 1 & - & + & $S$ \\
\hline 9 & 1984 & Jimbo & 37 & $M$ & 1 & day & $M$ & 1 & - & - & $S$ \\
\hline 10 & 1984 & Kohnosu & 24 & $M$ & 1 & year & $M$ & 1 & + & - & $S$ \\
\hline 11 & 1985 & Noguchi & 34 & $M$ & 3 & months & $M$ & 1 & - & + & $S$ \\
\hline 12 & 1985 & Noguchi & 42 & M & 6 & months & $M$ & 1 & - & + & $S$ \\
\hline 13 & 1985 & Iwashiro & 29 & $F$ & 4 & years & $M$ & 1 & + & + & $\mathrm{S}$ \\
\hline 14 & 1986 & Bandoh & 21 & $\mathbf{F}$ & 1 & year & $M$ & 1 & - & - & $S$ \\
\hline 15 & 1986 & Bandoh & 38 & $F$ & 7 & months & $?$ & $?$ & + & - & $S$ \\
\hline 16 & 1986 & Tsunoda & 25 & $M$ & 4 & years & M & 1 & - & - & $S$ \\
\hline 17 & 1987 & Ohmi & 59 & $M$ & 1 & year & $M$ & 1 & - & + & $\mathrm{S}$ \\
\hline 18 & 1987 & Kamiyama & 34 & $M$ & 11 & years & $M$ & 1 & - & - & $?$ \\
\hline 19 & 1987 & Kamiyama & 22 & $M$ & 10 & months & $?$ & 1 & - & - & S \\
\hline 20 & 1987 & Ozawa & 21 & $M$ & 2 & years & $?$ & 1 & - & + & $?$ \\
\hline 21 & 1988 & Sai & 37 & $F$ & 1 & day & $M$ & 1 & - & - & S \\
\hline 22 & 1988 & Futamura & 27 & $M$ & 6 & months & $?$ & 1 & - & + & $\mathrm{S}$ \\
\hline 23 & 1988 & Matsuzaki & 28 & $F$ & 1 & day & $M$ & 1 & - & - & $\mathrm{S}$ \\
\hline 24 & 1988 & Matsuyama & 24 & $\mathbf{M}$ & 3 & years & $M$ & 1 & - & - & S \\
\hline 25 & 1988 & Sugimoto & 20 & $F$ & 4 & months & M & 1 & - & + & $S$ \\
\hline 26 & 1988 & Miyakawa & 31 & F 1 & 1.5 & years & $M$ & 2 & - & + & $S$ \\
\hline 27 & 1988 & Iguchi & 27 & $\mathbf{M}$ & 1 & month & $?$ & 1 & - & + & S \\
\hline 28 & 1988 & Tsuno & 29 & $M$ & 1 & day & $M$ & 1 & - & + & $S$ \\
\hline 29 & 1989 & Hayashi & 27 & $M$ & 41 & years & $?$ & 1 & - & - & $\mathrm{s}$ \\
\hline 30 & 1989 & Hayashi & 29 & $F$ & $4)$ & years & $M$ & 2 & - & - & $S$ \\
\hline 31 & 1990 & Horie & 39 & $\mathbf{F}$ & 81 & years & $M$ & 1 & - & - & $\mathrm{S}$ \\
\hline 32 & 1990 & Ikeda & 24 & $M$ & 81 & years & $M$ & 1 & - & + & $\mathrm{S}$ \\
\hline 33 & 1990 & Hayashida & 32 & $\mathrm{~F}$ & 5 & years & $M$ & 1 & - & + & $S$ \\
\hline 34 & 1991 & Kuratate & 17 & $\mathbf{F}$ & 10 & months & $M$ & 1 & - & + & $S$ \\
\hline 35 & 1991 & Nishina & 42 & $M$ & $10 y$ & years & $A$ & 1 & + & + & $S$ \\
\hline
\end{tabular}

$\begin{array}{ll}\text { M: mesenteric border } & \text { S: survived case } \\ \text { A: antimesenteric border } & \text { D: dead case }\end{array}$

なお胃・十二指腸・肝臓・胆囊・脾臓・大腸などには 異常はなかった，腹腔内を温かい生理食塩液 $9.500 \mathrm{ml}$ で洗浄したのち, ペンローズドレーンを留置し, 閉腹 した.

病理組織検査：切除標本では腸間膜付着側に多数の 縦走潰瘍を認めた (Fig. 4). 腸間膜付着反対側の穿孔 部には，潰場はなかった，組織学的には全層珄にリン パ球浸潤や肉芽腫を認め, Crohn 病の所見であった (Fig. 5).

術後経過：術後経過は良好で, 第10病日から経口捸 取を開始した。第38病日内科へ転科し，第62病日退院 した，現在，外来で経過観察中である。

$$
\text { 考察 }
$$

Crohn 病における合併症のなかで，遊離穿孔はまれ
であり, 穿孔の頻度は約 1 〜 $3 \%$ とれている1), 穿孔 は大腸よりも小腸の方が多い2．われわれが検索した ところでは，Crohn 病による小腸の遊離穿孔の本邦に おける詳細な報告は34例にすぎなかった2) 31)，自験例 を加光35例について，その概要を Table 2 によぬ た。

年齢は17歳から92歳まで平均32.4歳で, 20〜30歳代 に多い. 性別は22：13で男性に多い，既往歴として肛 門疾患 7 例・虫垂切除術 8 例がみられた。 なお，症例 15 はチコ人, 症例 22 は中国人の症例であった。

穿孔部位は, 記載された27例のらち腸間膜付着側の 穿孔が25例で, 自験例の上らな腸間膜付着反対側の穿 孔はわずか 2 例であった。穿孔の原因として種々の因 子があげられるが，炎症・潰湯の急性増悪，狭窄によ 
る腸管内王の上昇の 2 者を指摘する報告が多い，自験 例では，腸間膜付着側に潰湯が存在するにもかかわら ず反対側の穿孔であること，狭窄の直前の拡張した腸 管が穿孔していること, 穿孔部には潰瘍はなかったこ とから腸管内圧の上昇による穿孔と考兄られた。

ステロイドの影響については, 穿孔例で投与されて いる症例が高率でないことから，あまり関与していな いとされている32). 本邦では術前に投与されていたの は, 自験例を含め 6 例だけであった。

穿孔の報告例では，病悩期間の短い症例, Crohn 病 の診断をうけていない症例や放置されていた症例が多 い. 病悩期間が 1 日以内の症例は 7 例であった。潰瘍 性大腸炎またはCrohn 病を疑われていた症例は 7 例 （症例 $4,12,13,15,18,33,34$ ）で, 症例 4,12 , 13，15はステロイドを，症例34はサラゾスルファピリ シンを投与され，症例33は放置されていた。 また症例 18は病悩期間が11年であるが, Crohn病として elemental diet 療法を始めて，6か月目に穿孔している。 自験例のように長期間治療を受けていた症例の報告は なかった。

われわれの症例は約 10 年間サラン゙ピリンやステロイ ドによる内科治療をらけており，小腸の狭窄とその口 側腸管の挔張を指摘されていた，腸管の位置や形態か ら，穿孔はこの狭窄に伴ら拡張部分に扢こったと判断 された。Crohn病による小腸狭窄において，いつ手術 にふみきるかは難しい問題である。この症例は狭窄を 指摘されてから6 年後に穿孔をきたしており，内科治 療の限界を示唆する症例と考学られる。

手術に扔いては, 穿孔部の単純閉鎖は縫合不全や再穿 孔の可能性が高く禁忌とされておう, 病変腸管の切除 と吻合が原則である ${ }^{130 / 33)}$. 病変部を完全に切除するこ とは重要であるが，小腸広範囲切除は避けた方がよい とされている34). Menguy はステロイド投与中の症例 や污染の強い症例では 2 期的手術を推奨している35). 本邦では全例に病変部切除と 1 期的吻合が行われ，死 亡は縫合不全の 1 例をふくめ 2 例であった，自験例で は穿孔後早期に手術ができたこと，健常部で吻合でき たことから 1 期的に吻合し, 経過は良好であった。し かし病変部をすべて切除しているわけではないので, 今後も慎重な保存治療が必要と思われる。

\section{文 献}

1) Greenstein AJ, Mann D, Sachar DB et al: Free perforation in Crohn's disease: A survey of 99 cases. Am J Gastroenterol $80: 682-689$,
1985

2）倉立真志, 國友一史, 河崎秀樹ほか：穿孔をきたし た小腸 Crohn 病の 1 例. 消外 $14: 509-514$, 1991

3) Yamase $K$, Inui $M$, Yamase $Y$ : Free perforation of regional enteritis. Int Surg $45: 29-33$, 1965

4) Sekoguti $T$, Kurabayashi $K$, Inoguchi $T$ et al: Free perforation in Crohn's disease. Mie Med J $25: 231-237,1976$

5）森瀬公友, 大館俊二, 林伸行ほか：穿孔をきたし た小腸クローン病の1例. 日消病会誌 78 : $91-95,1981$

6）大崎俊英, 香川茂雄, 高倉範尚ほか：呀孔性腹膜炎 をきたしたCrohn病の 2 例。臨外 37 : 587-591，1982

7) 渡辺正敏, 安部彦満, 旗福哲彦ほか：Crohn 病によ る小腸穿孔の 1 治験例。日消外会誌 15 : $1501-1505,1982$

8）田村利和, 高井茂治, 国友一史ほか：穿孔をきたし た小腸クローン病の1 例. 外科診療 25 ： $755-758,1983$

9）内田道男, 岩佐 裕, 根本浩介ほか：穿孔をきたし た小腸 Crohn 病の 1 例. 日外会誌 84： $1101-1106,1983$

10）勝又伴栄, 山本佳正, 五十嵐正厇ほか：回腸穿孔を 来したCrohn 病の 1 例. 胃と腸 $18: 1311-1315$, 1983

11）神保勝一, 服部了司, 大原 毅：突然穿孔したク ローン病の1 例. 日本大腸肛閒病会誌 37 : 628-631, 1984

12）鴻巣 寛, 山岸久一,野中雅彦ほか：小腸穿孔をき たしたクローン病の 1 治験例. 日臨处医会誌 $45: 745-750,1984$

13）野口友義, 浜野恭一, 次田 正注加：穿孔性腹膜资 をきたした小腸 Croohn病の 2 手術例. 日本大腸 肛門病会誌 $38: 380-385,1985$

14）岩城和義, 藤井恒夫, 曾我部仁史ほか：穿孔ををさ たした小腸 Crohn 病に広範冊切除を施行した 1 治験例。外科診療 $27: 105-109,1985$

15）坂東隆文, 豊島 宏, 武村民子：Crohn 病穿孔の外 科的問題点. 外科 $48: 945-949,1986$

16）角田明良, 片岡 徹, 桜井俊宏ほか：回腸穿孔を併 発したCrohn病の1例。日臨外医会誌 47： $1309-1315,1986$

17）大見良裕, 大木繁男, 城戸泰洋ほか：回腸穿孔を生 じたCrohn病の1例. 日臨外医会誌 48： 373-380, 1987

18）神山泰彦, 佐々木笅, 舟山裕士ほか：小腸穿孔を合 併した Crohn 病 2 症例の検討. 日本大腸肛門病会 誌 $40: 303-307,1987$

19）小沢 洋: 小腸疾患一 2 クロ-ン病. 蜂須賀喜多 
男, 中野 哲編，急性腹症の診断と治療. 医学図 書出版, 東京, 1987, p458-466

20) 佐井 昇, 長谷川洋, 寺崎正起ほか：回腸穿孔をき たしたCrohn病の1例。日消外会誌 21 : 949-952, 1988

21）二村 明,三島好雄, 岡安 勲ほか：Crohn 病の穿 孔一症例報告と本邦例の検討一. 外科治療 58 : 9-14, 1988

22）松崎正明,村瀬正治, 赤座 黄ほか：小晹穿孔をき たしたCrohn病の 1 例. 臨外 43:119-121, 1988

23）松山 薄, 大柳博樹, 渡久地到：Crohn 病による小 腸穿孔の 1 例. 青森中病医誌 $33: 235-238,1988$

24）杉本貴樹, 高橋信之, 永井公尚：穿孔をきたした小 腸クローン病の 1 例と本邦報告例の検討. 臨外 $43: 411-415,1988$

25）宮川秀一，山川 真, 三浦 馥ほか：穿孔性腹膜炎 をさたした小腸クローン病の 1 例. 腹部救急診療 の進歩 8:457-461, 1988

26）井口公雄, 宮内 卓, 福田雅武ほか：回腸穿孔をき たした小腸クローン病の1例. 日臨外医会誌 $49: 660-664,1988$

27）築野和男，泳沢三喜，小池 正ほか：回腸穿孔を
伴った Crohn 病の兄弟発症例. 日消外会誌 21 ： $2439-2442,1988$

28）林載鳳, 中村真已, 松村壕晃泳：姉弟に発症し たCrohn 病の 2 例。臨外 44:399-403，1989

29）场江泰夫, 千葉満郎, 児玉 光注か：回腸穿孔を起 こしたCrohn病の 1 例. 日本大腸肛門病会誌 $43: 455-460,1990$

30）池田浩之, 磯松俊夫, 杉井重雄注か：穿孔した小腸 Crohn 病と本邦報告例の検討. 外科 52 ： $312-316,1990$

31）村田一夫, 堀川 知, 秋山 博ほか：クローン病に よる回腸遊離穿孔の 1 例. 腹部救急診療の進歩 $10: 686-689,1990$

32) Steinberg DM, Cooke WT, Williams JA : Free perforation in Crohn's disease. Gut 14 : $187-190,1973$

33）杉田 周, 福島亘男, 土屋周二：Crohn 病穿孔. 手 術 43:643-649，1989

34）土屋周二, 竹内 浩：クローン病の治療と予後. 胃 と腸 $13: 517-526,1978$

35) Menguy R: Surgical management of free perforation of the small intestine complicating regional enteritis. Ann Surg $175: 178-189,1972$

\title{
Free Perforation of Ileum Due to Crohn's Disease - Report of a Case-
}

\author{
Masayoshi Nishina, Ryuko Ogino and Chiiho Fujii \\ Department of Acute Medicine, Kawasaki Medical School
}

A 42-years-old man was admitted to our service with acute onset of severe abdominal pain. His past medical history revealed that he had been on prednisolone and salazosulfapyridine for 11 years under the diagnosis of Crohn's disease, and an ileal stenosis secondary to the Crohn's disease was detected by radiological studies six years before admission. However the stenosis had been kept under observation by medical management since there was no definite sign of small bowel obstruction. On admission an initial evaluation of the patient yielded the picture of an acute abdomen due to a perforated viscus. Therefore an emergency laparotomy was performed and revealed a free perforation of the dilated ileum which was located on the antimesenteric side and proximal to the stenosis. A macroscopically pathologic segment of the small bowel was resected and a primary anastomosis was formed. The resected specimen showed stenosis and longitudinal ulcers which are consistent with Crohn's disease. Microscopic examination revealed inflammatory cell infiltration and granuloma formation. The postoperative course was uneventful and the patient was discharged on the 62 nd hospital day. This case suggests that one must keep in mind the possibility of free perforation of the intestine due to Crohn's disease during long-term medical care of the disease.

Reprint requests: Masayoshi Nishina Department of Acute Medicine, Kawasaki Medical School 577 Matsushima, Kurashiki-City, 701-01 JAPAN 